\title{
警察におけるステレオカメラの運用について \\ Operational Utilization of Stereo-Camera System in National Police Agency
}

\author{
浅川 章* \\ by Akira Asakawa
}

\begin{abstract}
It was in 1967 when the stereo-camera system was introduced to the traffic division of the National Police Agency in Japan. By the end of 1971, every prefectural police adopted it, and today 256 stereo-camera cars and 76 stereo-plotting instruments are under operation all over the country. They have made great contribution to the scientific inspection for the traffic accidents resulting in injury or death. Most of the stereo-camera cars are settled in the police stations and most of the stereo-plotting instruments are settled in the headquaters of the police. In 1977, exposured were approximately 90,000 scenes among in the traffic accidents, a stereo-camera car dealt with about 350 accidents and $30 \%$ of them were mapped on papers by the stereo-plotting instrument.

There exist principal advantages in stereo-camera system as follows:

1. Accurate inspection of real condition and rapid field activities

2. Scientific measurement of damaged car on the traffic accident spot

3. Application for the analysis of traffic accident

4. Contribution for the Synthetic policy of traffic safety

5. Application for the identification activities on the spot in complex and massive affairs or accidents

On the other hand, there exist problems of stereo-camera system in the National Policy Agency, deterioration of the stereo-camera, education of freshmen for the operation as well as technical improvement of equipments.

The benefits of stereo-camera system are extremely powerful over versatile fields in police activity.
\end{abstract}

梗概 日本において，交通警察部門にステレオカメラが導入されたのは1967年であり，1971年には全都道府県警察に 採用され，今日では，全国でステレオカメラ256台, 立体図化機76台が運用され，交通人身事故に対する科学的捜查活 動の柱として活躍している。

その運用状況は, ステレオカメラは, そのほとんどが警察署, 立体図化機は, そのほとんどが警察本部に設置され， 1977 年には全国で約 46 万件の交通人身事故が発生したが，このうち約 9 万件を撮影しており，1台当たりの撮影件数は 約 350 件である。撮影件数の約 3 割が立体図化機により図化されている。

ステレオカメラの主な効果として, 交通事故現場の正確な実況見分と現場の再現性の確保, 現場活動のスピード化, 衝 突車両の損傷状況の科学的測定等をはじめ, 交通事故分析への活用と交通総合安全対策への貢献や複雑, 大規模な事故事 件における現場鑑識活動への活用等があげられ，その効果は多方面にわたり，極めて大きい。

日本警察におけるステレオカメラ運用上の若干の問題点としては，ステレオカメラの老朽化，カメラ操作の不慣れの克 服, カメラ機器の技術的改善の推進等があるが, 当面の課題としては, ステレオカメラの性能, 効果に対する評価を部内 で確立し, 交通警察中心の運用から複雑, 大規模な事故, 事件への活用, 即ち, 多方面高度利用の推進がある。

\section{1. 警察におけるステレオカメラの導入}

ステレオカメラを用いて交通事故現場を測定し，交 
等ヨーロッパの警察の一部で採用されていたが，わが 国では, 埼玉県警が昭和 42 年, 西独ツァイス社のステ レオカメラ, 図化機を導入し, 同年12月から同県の主 要幹線道路の一部に採用したのが最初である。

続いて, 昭和 44 年に, 神奈川, 広島, 岡山の各県警 で, 更に 45 年に長野, 大阪, 石川, 杤木, 兵庫, 警視 庁で，それぞれ運用が開始され，同年には，ステレオ カメラ, 図化機の国産品も製作され, 使用された。

警察庁では，ステレオカメラによる交通事故事件捜 査の合理化を全国的に推進することとし, 昭和 45 年度 予算でステレオカメラ 252 台, 図化機 74 台の補助金を 獲得した。

これに基づいて, 各都道府県は, 早急に整備に取り 組み, 昭和46年度から全都道府県警察で運用が開始さ れ，今日に至っている。

\section{2. ステレオカメラの運用状況}

昭和 52 年末現在のステレオカメラ及び図化機の整備 状況は，全国で，ステレオカメラ 256 台，立体図化機 76 台であり, 46 年当時と比べ大差なく, ほぼ安定状 態にある。

ステレオカメラの運用形態についてみると, 警察署 だけの運用が約 8 割と多く, 若干の府県で, 集中運用 と署運用の併用, 集中運用のみという形態にある。

昭和 52 年中における全国のステレオカメラ配置署 （隊）の交通事故発生件数（人身事故に限る。）は約 22 万 7,000 件で，これに対する撮影件数は約 8 万 9,800 件で, 撮影率は約 $40 \%$ となっている。撮影率は, ここ 数年 4 割前後で推移している。

都道府県別でみると, 撮影率が高いのは高知, 石川, 岩手などで， $80 \%$ を回っている。

全国で発生した人身事故の $49 \%$ に当たる約 22 万 7,000 件がステレオカメラ配置 (隊) 管内で発生して いるが，これはステレオカメラ 1 台当たり約 890 件で ある。

これに対し，ステレオカメラ 1 台当たりの撮影件数 は全国平均で 350 件で，撮影率約 $40 \%$ である。

次に, ステレオカメラによる撮影の対象範囲は, 原 則として全人身交通事故を対象としている。また，図 化対象範囲は，おおむね負傷程度 1 ケ月以上又は 3 ケ 月以上の全人身交通事故を対象としているが，都道府 県により差がある。最近では, 撮影件数の約 3 割が図
化されている。

\section{3. ステレオカメラの効果}

ステレオカメラの主な効果は, 次のとおりである。

\section{1 実況見分の正確性と現場の再現}

ステレオカメラの効果として特に重要なことは, 実 況見分の際の特定地点の測定が正確に行われるばかり でなく，必要なときに事故現場が正確に再現できるこ とである。

また，交通事故捜査にステレオカメラを使用した場 合は，乾板に写されている写真像をもとに現場の状況 や必要な関係地点間の距離等を室内作業によって精密 測量機械である立体図化機を用いて精密な現場縮尺困 面を作成することができるので，巻尺による測定の場 合のように，测定誤りや測定もれがなくなり，客観的 な信頼度の高い実況見分ができることになる。

更に，現場を撮影した乾板を保管しておくことによ って，後日になって新たな事故に関係する地点の位置 や高さなどを求めたい場合，再見分の必要がなくいつ でも図化機によって測定することができる。つまり， 変化の早い道路環境にかかわりなく, 事故当時の現場 が半永久的に保存でき， いつでも再現可能であること は，後日当事者間に紛争が生じた場合や刑事裁判や民 事裁判等で事実関係や過失認定に必要な場合において も，保管されている乾板が担保となり，紛争が少ない などその効用は非常に大きい。

\section{2 現場処理のスピード化}

ステレオカメラによる実況見分の場合は，現場にお ける捜査, 又は調査に必要な関係地点が確定されれば, 事故現場の関係地点や周辺の状況等を含めステレオカ メラによって撮影され，図化機で正確な立体測定がで きるから，巻尺による測定記録が不要となる。したが って，簡単な事故現場の場合にはあまりかわらないが， 事故現場の範囲が広かったり，現場が複雑な場合には 現場処理時間が相当に短縮される。

その結果, 交通渋滞の早期解消, 職員の受傷事故, 二重事故の防止等の効果がある。

\section{3 交通事故捜査の分業化}

従来の交通事故捜査の場合には，現場に臨場して実 
況見分を行った警察官が現場図面を作成していたが， ステレオカメラを使用した場合は, 交通事故現場の写 真撮影作業を中心とする現場作業と，その写真をもと にする作図作業とは別の者が行うことができるので, 分業専門化が可能となる。

また, 図化作業に従事する者は, 警察官である必要 はないから，交通事故捜查過程に一般職員を導入する ことができる。

\section{4 交通事故鑑定の利用}

ステレオカメラで衝突車両を撮影すると, 立体的に 観察ができ，その損傷状況等を正確に測定できるので， これをもとに衝突箅所, 方向, 速度等を科学的に判断 することができるなど，鑑定上の利用効果が大きい。

\section{5 立体観察の利用}

ステレオカメラの写真は, 図化機による位置, 高さ の測定や図面を作成するだけのものでなく，立体視し ながら観察すること（判読という。）も重要な利用分野
になっている。例えば, 写真を立体視することによっ て, 机上でミ二現場を再現して, 現場状況の観察, 車 両人体等損傷部位の観察などに利用することができ, 現場状況や損傷物体等について, 現場実分者, 当事者 の再確認方法, 警察幹部, 検事, 判事等事故状況を見 ていない者に対する説明などにも効果的である。

\section{6 交通事故分析への活用と交通総合安全対策の 推進}

交通事故現場の道路状況, 安全施設の状況等を含め てすべて正確に，しかも詳細に記録されているので, 交通事故分析に役立つことはいうまでもなく，交通規 制, 交通管制の適正化や道路改良等交通総合安全対策 の推進にも貢献できる。

\section{7 複雑・大規模な事故事件の現場鑑識への活用}

航空機・列車事故やガス爆発事故，バス転落事故を はじめ刑事事件，暴走族の集団暴走事件等，複雑，大 規模な事故事件については，検証や実況見分の際に巻

\begin{tabular}{|c|c|c|c|}
\hline $\begin{array}{l}\text { 区分 } \\
\text { 番号 }\end{array}$ & 件 & $\begin{array}{ll}\text { 撮 } & \text { 影 } \\
\text { 年 } & \text { 県 } \\
\text { 日 }\end{array}$ & 影 \\
\hline 1 & 屋外殺人事件 & $\begin{array}{l}\text { 神 奈 川 県 } \\
45.4 .25\end{array}$ & $\begin{array}{l}\text { 殺人現場の状況および人, 物の存在, 損傷 (壊) の状 } \\
\text { 洗を明らかにするため }\end{array}$ \\
\hline 2 & 崩壊土砂の下敷死亡事件 & $\begin{array}{l}\text { 神 奈 川 県 } \\
46.12 .10\end{array}$ & $\begin{array}{l}\text { 団地造成作業中, 崩壊土砂に埋った作業員 } 15 \text { 人が死 } \\
\text { 亡した土砂量を算出するため }\end{array}$ \\
\hline 3 & 廃棄物 不法投棄事件 & $\begin{array}{l}\text { 神 奈 川 県 } \\
48.4 .13\end{array}$ & 投棄物の集積現場から投棄物の量を算出するため \\
\hline 4 & プロペラシャフト落下死亡事件 & $\begin{array}{l}\text { 神 奈川 県 } \\
50.1 .14\end{array}$ & $\begin{array}{l}\text { 脱落したプロペラシャフトによる被害車両の損壊状況 } \\
\text { を明らかにするため }\end{array}$ \\
\hline 5 & 貨物列車脱線転覆事故 & $\begin{array}{cc}\text { 滋 賀 } & \text { 県 } \\
49.11 . & 3\end{array}$ & $\begin{array}{l}\text { 駅構内における貨物列車の脱線転覆状況および現場の } \\
\text { 状況を明らかにするため }\end{array}$ \\
\hline 6 & 石油タンク火災事件 & $\begin{array}{ll}\text { 三 重 県 } \\
50 . & 3 .\end{array}$ & $\begin{array}{l}\text { 製油所における原灯油火災現場およびタンクの毁損状 } \\
\text { 洗を明らかにするため }\end{array}$ \\
\hline 7 & 電車の衝突脱線転覆事故 & $\begin{array}{l}\text { 京 都 府 } \\
50.4 .17\end{array}$ & $\begin{array}{l}\text { 踏切上の電車と乗用車の衝突により乗客7 } 1 \text { 人が重軽傷 } \\
\text { を負った現場の状況を明らかにするため }\end{array}$ \\
\hline 8 & 橋析 崩落事件 & $\begin{array}{l}\text { 京 都 府 } \\
51.1 .17\end{array}$ & $\begin{array}{l}\text { 歩道橋架橋工事中, 橋栴が水中に崩れ落ち作業員 } 8 \text { 人 } \\
\text { が死傷した現場の状洗を明らかにするため }\end{array}$ \\
\hline 9 & $\begin{array}{l}\text { 過激派による三菱重工ビル爆破事 } \\
\text { 件 }\end{array}$ & $\begin{array}{l}\text { 警 視 庁 } \\
49.9 .26\end{array}$ & $\begin{array}{l}\text { 爆破現場付近駐車中の損傷車両から，爆薬量を算出す } \\
\text { るため }\end{array}$ \\
\hline 10 & パイパー機による児玉邸激突事件 & $\begin{array}{l}\text { 警 視 庁 } \\
51.3 .23 \\
\end{array}$ & 激突が過失か否かを明らかにするため \\
\hline 11 & フィリッピン航空機離陸暴走事件 & 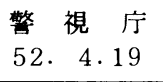 & $\begin{array}{l}\text { 羽田空港における滑走痕など現場の状況を明らかにし, } \\
\text { 事故原因を究明するため }\end{array}$ \\
\hline
\end{tabular}




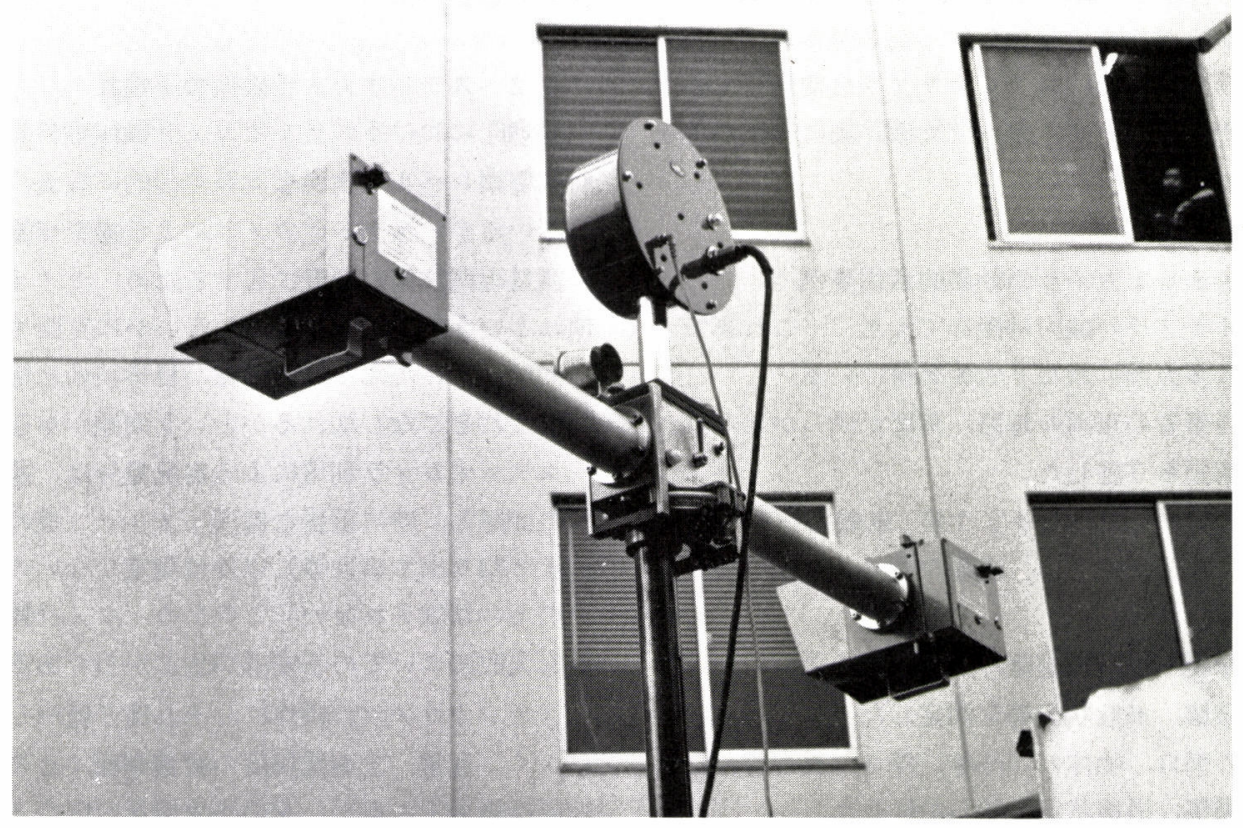

ステレオカメラ本体

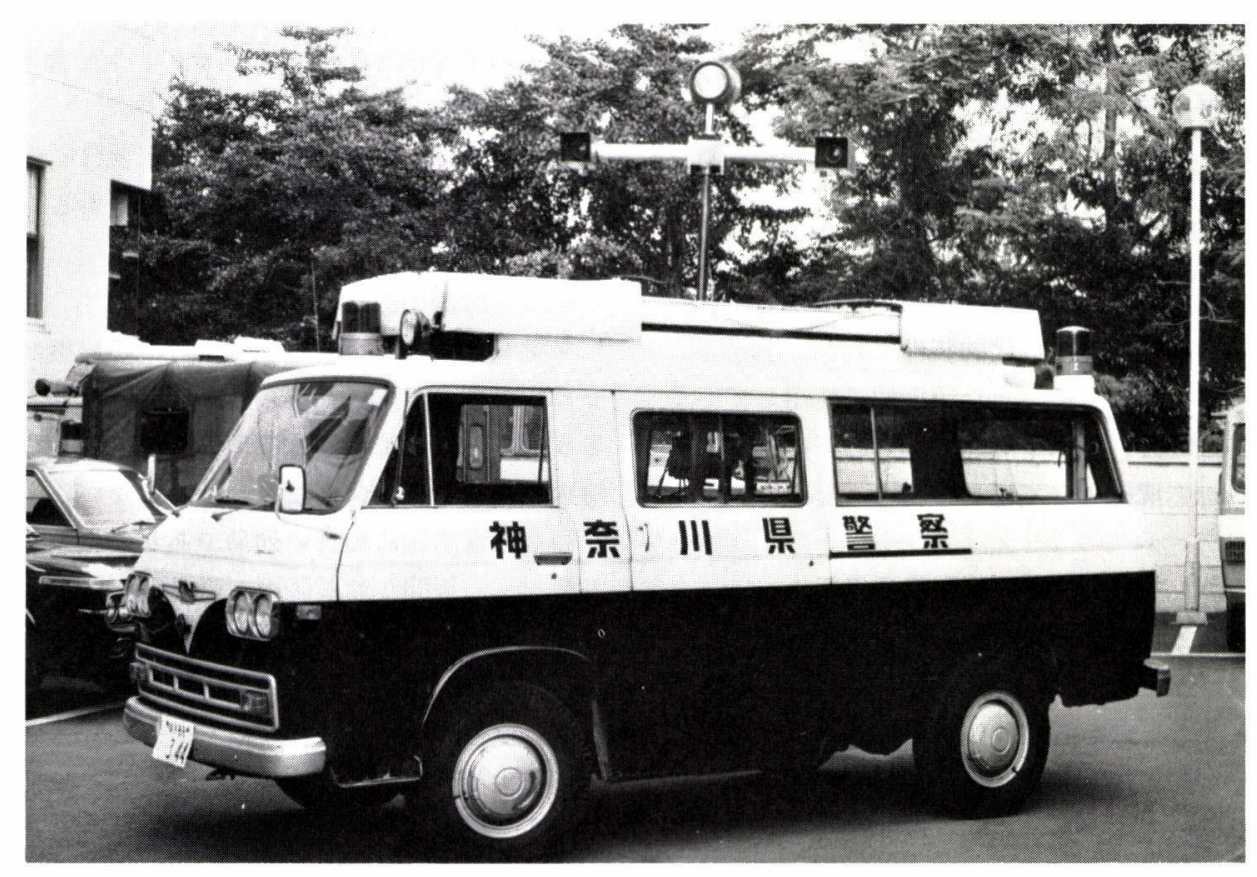

ステレオカメラと搭載車 
尺を用いて行うことは，相当の長時間を要するばかり でなく，測定が複雑で困難を伴う場合が多い。

このような場合に，ステレオカメラを使用して必要 範囲を撮影しておけば, 室内で正確詳細に作図ができ るのでその効果が大きい。

\section{8 ステレオカメラの効果的活用事例}

ステレオカメラの威力は極めて大きく，これまでつ ぎのように多方面にわたり成果を得ている。

- 事故当事者の車両の進路, 角度が明らかとなり, 過失認定を立証した。

・現場のスリップ痕・タイヤ痕・車轍痕から, 長さ, 深さ, 強弱を測定し, 速度の算出, 車種の割出し をした。

- 列車転覆, 飛行機陪落, 爆弾爆発の現場における 物の破壊, 飛散状況等を測定した。

・人間の傷口，物体の凹凸等，深さ，長さ等を測定 し，損傷，損壊状況を明らかにした。

-投棄物，又は土砂等の崩壊現場から，面積，体積 を算出した。

・高層建築物，鉄塔等の高さを測定した。

- 飛行機の飛行高度を測定し, 故意によるものか否 かを明らかにした。

具体的活用事例は前表のとおりである。

\section{4. ステレオカメラ運用上の若干の問題 点と対応}

前述のようにステレオカメラには大きな効果があり， また時代の要請に応じた近代的装備であるが，問題は， この機械をいかに適正に，また積極的に使用していく かということにあり，以下，運用上の若干の問題点及 びそれへの対応策について述べる。

\section{1 ステレオカメラ及び搭載車の老朽化}

ステレオカメラの耐用年数は, メーカーの機種によ り多少の差はあるものの $5 \sim 7$ 年といわれ，また， ス テレオカメラを搭載する事故処理車の耐用年数は，お おむね 7 年が限界である。しかし，昭和 46 年以降，各 都道府県警察に導入されているステレオカメラ及び搭 載車は，予算難等の理由により減耗補充はほとんどな されていない。このため，一部で故障が目立ち，修理 費の不足もあって，使用率を伸張できない一要因とな っている。したがって，計画的な减耗更新を強力に推
進する必要がある。

\section{2 ステレオカメラ操作の不慣れ}

警察庁におけるステレオカメラ操作専科教養, 都道 府県警察レベルの指導教養等全国的に教養訓練を継続 しているが，ステレオカメラによる撮影作業は，高度 な測量専門技術の分野に属するため，カメラ操作の不 慣れという問題があり，これをいかに克服するかとい う問題，いいかえると，警察が科学技術と格闘してい かにこれをこなし切れるかという問題がある。

ステレオカメラ利用による実況見分は，基準点コー ンの間隔と，特に重要な箇所（スリップ痕の長さから 速度を割り出す場合等）以外は測定しないので，撮影 上のミスは許されない。このため，カメラ操作員には 撮影失敗についての不安感が生じがちである。

ステレオカメラの操作は，それほど難かしいもので はなく, 通常, 1 週間程度の教養訓練でその取り扱い 技術は修得できるが，交通事故搜查の中心となってい る捜査責任者には比較的中高年者が多く，一部にはス テレオカメラになじめない傾向もあって，従来の巻尺 測定に安易に流れる傾向があり，巻尺測定とステレオ カメラ撮影とによる重複測定ということになると，現 場処理の迅速化といらステレオカメラを導入した効果 は大きく減殺されるおそれさえある。

したがって，カメラ操作員や図化要員に対する組織 的，系統的な教養訓練の強化が課題である。

\section{3 機器の改良及び導入}

ステレオカメラを使用中, 搭載車の屋根が開放状態 であるため, 導入当初から, 雨天時には車内に水がた まり，ストロボ等の保守管理上問題となっているので, 雨水除けの方法を考えなければならない。

わが国は南北に細長い列島であり，気象条件の変化 も激しく, 年間を通じ降雨, 降雪量が多い。こういう 特異気象時には，交通事故や重大特異事故の発生もま た多いので，すでに一般用として開発されている全天 候カメラをステレオカメラにも取り入れることの可否 を研究する必要がある。

現在，警察が使用しているステレオカメラは，外国 製・国産品いずれも基線長は $120 \mathrm{~cm}$ で，その機能上ご く近距離間の撮影には不向きである。しかし，各種事 件搜査の過程では, 例えば車両の損傷部分, 痕跡部 分, 屋内現場, 死体解剖の撮影等, 被写物件の近距雔 
扡大撮影が必要であり, 現状では, これらの撮影には 一般用カメラで補充撮影している。しかし, 基線長が 短く, 携帯用バッグに収納でき, 小回りのきく小型ス テレオカメラの導入が考えられるべきであろう。

\section{4 多角的運用の推進}

ステレオカメラは, 昭和 46 年度の全都道府県警察運 用開始以来, 激増しつつあった交通事故に対する科学 捜査活動のエースとして交通部門に配置され，現在ま で，交通警察中心に運用されてきたが，ステレオカメ ラの性能及び効果を考えるとき, その運用範囲は, 交 通部門だけに限られるものではない。

例えば, 殺人, 火災, ガス爆発, 過激派の爆弾事件, 飛行機の墜落, 列車転覆, 大規模災害等の現場撮影等
警察活動全般に及ぶ範囲に運用できるものである。

しかも近年, 人口の都市集中による過密社会の現出, 科学技術の進歩, 大量交通機関の発達等の社会環境の 激変に伴い，警察事象が量的質的に抗大し，より複雑 多岐にわたっている遛勢から，なおさらである。

しかし，実情は各都道府県警察とも，他部門での活 用は低調で，県によっては，交通部門以外には全く活 用されていないところもあり，警察組織全体の効率的 な業務運営上マイナスと思われる。

ステレオカメラについては, 部内外にもっと P R を 強め, 幹部をはじめ警察組織全体の認識の高揚に努め, その効率的, 効果的運用を推進していくことが要請さ れている。

(1978.9.22 受付) 